\title{
Brexit and Gibraltar: the Spanish proposal for joint sovereignty
}

\author{
José MARTÍN Y PÉREZ DE NANCLARES*
}

\begin{abstract}
The result of the referendum held in the United Kingdom on 23 June 2016, which favoured withdrawal from the European Union, marked the entry into a new legal and political context which will have important consequences not only for the UK, but also for the EU and all its Member States. In this scenario, Brexit and Gibraltar are intimately connected, so that the United Kingdom's departure from the Union would have profound consequences for Gibraltar. The most obvious consequence is that the withdrawal of the United Kingdom from the Union will inevitably produce the withdrawal, too, of Gibraltar, since the legal tie established by Article 355.3 TEU will disappear. In fact, there is no legally-acceptable justification for seeking 'precedents' by reference to micro-States or to the notion of 'reverse Greenland' to bring about the chimera that Gibraltar could remain within the Union even if the United Kingdom were no longer a Member State. Besides, as Gibraltar is the object of a dispute over sovereignty, over which the Union has no jurisdiction, the bilateral Spanish-British approach should be scrupulously respected in the negotiations held between the EU and United Kingdom regarding the 'sovereignty issue'. In this context, the Spain's proposal for shared sovereignty, presented by the IV UN Committee on 4 October 2016 , could be a good deal for all or at least could be a good starting point for negotiation.
\end{abstract}

Keywords: Brexit - Gibraltar - shared sovereignty - Article 50 TEU - Article 355 TEU - UN $4^{\text {th }}$ Committee

\section{(A) INTRODUCTION: BREXIT AND GIBRALTAR, CLOSELY-RELATED QUESTIONS}

The result of the referendum held in the United Kingdom on 23 June 2016, which favoured withdrawal from the European Union, marked the entry into a new legal and political context which will have important consequences not only for the UK, but also for the EU and all its Member States. In consequence, a complex negotiating process between the UK and the EU must now be undertaken. As well as establishing the mode of withdrawal by the first Member State to decide to leave the Union, these negotiations will also have to set out the conditions governing the future relations between this State and the EU. And all parties are well aware that the outcome of these negotiations will also create a template that other Member States, perhaps tempted to follow the same path as the UK, could hypothetically employ in the future.

The unexpected scenario of Brexit will undoubtedly bring about many and varied consequences, most of which are probably still ill-defined at this early stage in the process. But from the outset it was absolutely clear that the United Kingdom's departure from the Union would have profound consequences for Gibraltar. The Gibraltarians had no doubt at all, even before the referendum was held $^{\mathrm{I}}$, that a British exit from the Union would gravely imperil the favourable legal regime that this

* Professor of Public International Law, University of Salamanca (Spain). Head of the International Legal Office, Spanish Ministry of Foreign Affairs and Cooperation. The opinions expressed in this paper are the author's own, and cannot be attributed in any way to the institution at which he is currently employed.

I Not surprisingly, unlike the narrow margin of the outcome of the referendum in the United Kingdom (51.89\% leave vs. $48.11 \%$ remain), it was clearly perceived in Gibraltar that British withdrawal from the EU would have very negative consequences for this territory. It is understandable, therefore, that $95.9 \%$ of the voters in Gibraltar (19,322 votes) favoured remain, while only $4.1 \%$ voted leave ( 823 votes). Indeed, the British Foreign Secretary, Philip Hammond, acknowledged "that Brexit would threaten sovereignty and 'seriously impair' the Government's ability to stand up for Gibraltar, and would 
territory had achieved when the UK, Ireland and Denmark acceded to the then European Communities'. At that moment, even before Spain became a Member State of the Union, Gibraltar was considered to be a territory whose external relations were the responsibility of a Member State (Article 355.3 TEU), namely, the United Kingdom³. It is quite apparent, therefore, that Gibraltar and Brexit are intimately connected ${ }^{4}$. Moreover, and perhaps for the first time since the Treaty of Utrecht, a window of opportunity has opened, by which a reasonable solution may be sought to the long-standing dispute over Gibraltar, which, when all is considered, presents the anachronism of being the last remaining colony in Europe. Thus, it can be no surprise that the Spanish Government, at this opportune moment, has given serious consideration to designing a proposal that would enable a favourable outcome not only for Spain and the United Kingdom, but also for the Gibraltarians themselves and the inhabitants of the neighbouring area of Campo de Gibraltar.

Accordingly, in this new context, on 16 September 2016, the Minister of Foreign Affairs and Cooperation, José Manuel García-Margallo, sent a letter to his British counterpart, inviting him to resume the talks that had begun following the 1984 Brussels Declaration, with a view to reaching a bilateral agreement prior to determining the status of Gibraltar arising from the Brexit negotiations. The Spanish Minister also informed the Foreign Ministers of the other EU Member States, as well as the Presidents of the Commission and the European Council, of this proposal. Consequently, the

'endanger Gibraltar's future security and prosperity”. Moreover, Brexit “would be as big a threat to Gibraltar's future security and Gibraltar's future sovereignty as the more traditional threats we routinely talk about" (Gibraltar Chronicle, I2 May 2016 ). In fact, now that the referendum results are known, the British Government has unequivocally shown its concern about the proposal made by the Spanish Minister for Foreign Affairs and Cooperation to revive the 2002 idea of co-sovereignty, to which we refer below; HOUSE OF COMMONS, Brexit: what happens next?, London, 30 June 2016, p. 21.

Furthermore, it could well be said that the British Government had, in a way, anticipated the Spanish reaction. Thus, it has officially and openly acknowledged its concern that Spain might take advantage of the United Kingdom's withdrawal from the EU in relation to Gibraltar ("It also bighlighted the importance of the EU to its economy, and expressed concern that Spain would take advantage of a UK exit from the EU to 'further undermine, isolate and exclude Gibraltar from the European mainstream") and has reiterated the understandable commitment to ensure the proper protection of Gibraltar in a context of this nature (The UK must immediately act to protect Gibraltar from such actions in the event of a vote to leave the EU); HOUSE OF COMMONS, Implications of the referendum on EU membership for the UK's role in the world, London, 26 April 2016 , pp. 19-20, paragraph 31 .

2 Without entering into great detail, let us note that Gibraltar was excluded at the time from the application of EU rules on customs union, common commercial policy, common agricultural policy and common fisheries policy, as well as the obligation to collect VAT. Moreover, it does not form part of the Schengen area (Article 28 of the 1972 Act of Accession, by Denmark, the United Kingdom and Ireland). This situation was consolidated with Spain's accession, when a Declaration by Spain and the United Kingdom was included, stating that "The Treaties apply to Gibraltar as a European territory for whose external relations a Member State is responsible. This shall not imply changes in the respective positions of the Member States concerned". In this respect, valuable insights are provided in the publication by Cristina IZQUIERDO SANS, Gibraltar en la Comunidad Europea: consecuencias sobre el contencioso bispano-británico y el proceso de construcción europea [Gibraltar in the European Community: consequences for the Spanish-British dispute and the process of European construction], Madrid, 1996.

Former Article 227.4 TEEC. This is not the moment to dwell on the peculiarities of this precept, although the reasons for its original inclusion in the founding treaties could be profitably investigated. It is an article which, in fact, was already present in the previous Treaty establishing the ECSC (Article 79) and whose raison d'etre is discussed in the doctrine. It is clear, in any case, that, apart from its possible historical explanations, it has provided the Union with the necessary flexibility in relation to certain territories with special characteristics.

4 See HOUSE OF LORDS: Brexit: Gibraltar, HL Paper in6, London, I March 2017.

5 The British position is known to be that of demanding a return to the Tripartite Forum and to recalling that the United Kingdom will not enter into any negotiating process that does not have the backing of Gibraltar. 
Spanish Permanent Representative to the United Nations presented the proposal to the 4th Committee on 4 October 2016 and described its main features 6 . Basically, the proposal was for Spain and the United Kingdom to exercise joint sovereignty over Gibraltar, with both States taking responsibility for defence, foreign relations, border control, asylum and immigration; all other competences would correspond to Gibraltar, whose population, moreover, would be guaranteed a personal statute that maintained their British nationality and also facilitated access, if so desired, to Spanish nationality.

Before entering into further detail, we first analyse, from a purely legal and academic perspective, the scope of the Spanish proposal within the context of Brexit. Then, after a brief description of the doubts and certainties contained within the legal framework established for Brexit by the EU founding treaties (II), we analyse the proposal for shared sovereignty (III), and show that some of the 'creative' options being aired in Gibraltar to maintain unchanged their current relationship with the Union are, in fact, pure fantasy (IV). Finally, in some brief closing remarks, we will try to show that the Spanish proposal for shared sovereignty is a 'win-win' proposition that benefits all concerned, although, logically, nobody's initial aspirations will be fully satisfied (V).

(B) THE LEGAL FRAMEWORK FOR BREXIT: MANY DOUBTS, BUT ALSO SOME CERTAINTIES

\section{(I) The doubts about Brexit: difficulties arising from the lack of precedents}

At present, any discussion of Brexit immerses us in a turbulent sea of doubts. As yet, little can be said with certainty, apart from the United Kingdom's 'intention' to activate, in the near future-perhaps at the end of March, coinciding with the 6oth anniversary of the signing of the Treaty of Rome-the withdrawal mechanism provided for in Article $50 \mathrm{TEU} 7$. We find ourselves, therefore, in a landscape whose main feature is uncertainty. By way of illustration, a number of doubts immediately come to mind that are directly relevant to the matter at hand and to which no definite answer can yet be given ${ }^{8}$.

6 This is well summarised in A/C/.4/71/SR.3, pp. 2-3.

7 This provision establishes the following: "I. Any Member State may decide to withdraw from the Union in accordance with its own constitutional requirements. 2. A Member State which decides to withdraw shall notify the European Council of its intention. In the light of the guidelines provided by the European Council, the Union shall negotiate and conclude an agreement with that State, setting out the arrangements for its withdrawal, taking account of the framework for its future relationship with the Union. That agreement shall be negotiated in accordance with Article 2I8(3) of the Treaty on the Functioning of the European Union. It shall be concluded on behalf of the Union by the Council, acting by a qualified majority, after obtaining the consent of the European Parliament. 3. The Treaties shall cease to apply to the State in question from the date of entry into force of the withdrawal agreement or, failing that, two years after the notification referred to in paragraph 2, unless the European Council, in agreement with the Member State concerned, unanimously decides to extend this period. 4. For the purposes of paragraphs 2 and 3, the member of the European Council or of the Council representing the withdrawing Member State shall not participate in the discussions of the European Council or Council or in decisions concerning it. A qualified majority shall be defined in accordance with Article 238(3)(b) of the Treaty on the Functioning of the European Union. 5. If a State which has withdrawn from the Union asks to rejoin, its request shall be subject to the procedure referred to in Article 49."

8 For a more detailed analysis of these doubts, see in Spanish our contribution La Unión Europea ante el desafío del Brexit: de la Decisión de los Jefes de Estado y Gobierno a la activación de procedimiento de retirada [The European Union and the Brexit challenge: from the Decision by the Heads of State and Government to the activation of the withdrawal procedure], 43 Actualidad Jurídica Uría-Menéndez (2016) 7-23, especially at pp. 17-22. 
From the outset it must be determined whether the notification provided for in paragraph two of Article 50 TEU can be revoked once it has been submitted. This is no trivial remark because, apart from purely legal considerations the interpretation of which is ultimately up to the Court of Justice of the European Union (CJEU), one question would be that of entering into a negotiating process in which the UK knows that it has the option of withdrawing its notification if the negotiation does not transpire as it wishes-for example, one day before the end of the two-year deadline for the conclusion of the negotiations-and quite another situation would arise if this option did not exist. Certainly, despite the present doctrinal controversy in this regard, it would be difficult to argue that, if a British change of opinion were to occur as a consequence of a second referendum or even a change of government, a reversal could not be allowed.

It is also unclear whether the general guidelines to be adopted by the European Council by consensus are final or whether they may follow the rhythm of the notifications, through successive guidelines. Neither is it stated just how specific these guidelines should be. This, too, is no secondary issue for the subject at hand. As the approval of the general guidelines is the only moment at which decisions are taken by consensus and therefore at which the Member States have real capacity to exert pressure, it is obviously important for the EU to stipulate the terms according to which negotiations will take place. In the case of Gibraltar, this is the crucial moment for establishing the Union's position in this regard. And, in our view, it is hard to imagine a scenario in which the European Council, once the general guidelines have been adopted, might exclude absolutely itself from the negotiations and leave the whole process to the Council, which decides questions by a qualified majority.

At the institutional level, the role of the Commission in the negotiations is equally uncertain, since the referral by Article 50.2 TEU to Article 2I8.3 TFEU does not include any express reference to the Commission. The same applies to the CJEU, since doubts also arise as to whether, in view of the above-mentioned referral of Article 50 TEU to Article 218.3 TFEU (and not Article 2I8.II TFEU), the judicial review addressed in its paragraph in could be performed in relation to the international agreement(s) concluded between the Union and the United Kingdom-to say nothing of the effect that this uncertainty might have on the supervision of negotiations and on the interpretation of legal questions that could arise with respect to any of the terms set out in Article 50.2 TEU. In our view, according to the wording of Article I9 (I) TEU, it cannot realistically be denied that the CJEU, sooner or later, could deliberate on the issues raised and issue a preliminary ruling (Article 267 TFEU) or even make a hypothetical action against the United Kingdom for non-compliance with Union law in matters relating to Article 50 TEU during the negotiations (including the duty to act with loyalty and in good faith, as provided for in Article 4.3 TEU). Indeed, it is even possible to conjecture a situation in which an action might be brought to annul one or more decisions by the institutions of the Union (Article 263 TFEU).

In fact, to date we do not even have a consensus on the legal nature of the eventual agreement reached between the Union and the United Kingdom (EU-only or mixed agreement), or on whether everything would be compiled within a single agreement or, alternatively, split into two different agreements (a very concise one on withdrawal and another more complex one to determine future relations between the UK and the Union). Nor is it clear whether the agreement would require a 
parallel reform of the founding treaties. As can readily be imagined, this consideration has very significant consequences in the matter addressed in this paper. To say the least, the requirement or otherwise for the agreement to be ratified by the parliaments of all Member States would determine whether each Member State had a second possibility to reject the entry into force of the international agreement negotiated between the Union and the United Kingdom', in addition to whatever may be indicated in the general guidelines adopted by the European Council.

Lastly, there is some controversy as to how many times the two-year deadline for negotiation could be extended (for one year) and the specific consequences of exceeding this deadline without any agreement being reached. It could be even possible that in such a situation the international law order should play a key (interpretative) role as instrument to fulfil the possible legal gaps of Article 50 TEU. The lack of clarity is such that, in practice, we do not even know what effect the exit process would have on the application of the principle of international law that withdrawal must "... not affect any right, obligation or legal situation of the parties created through the execution of the treaty prior to its termination" (Article 70.I (b) Vienna Convention on the Law of Treaties, 1969). Depending on how it is interpreted, such could be the outcome, however, both for Britons residing in EU Member States and for nationals of Member States residing in the UK, and further problems in this respect would also arise, for example concerning the British officials currently working in the European institutions.

\section{(2) The certainties of Brexit: indisputable aspects derived from the legal framework established by the founding treaties}

Nevertheless, the existence of legal doubts as to the implementation of the mechanism for withdrawal does not in any way mean that everything may be negotiated to determine the future conditions of the relationship between the United Kingdom and the Union. On the contrary, while some major areas of doubt are apparent, there are also certainties that cannot be ignored and whose effect on the issue at hand is of capital importance. Firstly, unlike what might have been supposed before the entry into force of the Treaty of Lisbon, any action must be located within the legal framework established by the aforementioned Article 50 TEU. A degree of flexibility can be granted to these provisions, since their practical application frequently leaves room for interpretation, but no support can be given to actions not admitted under the procedure established for this purpose by the founding treaties. Therefore, no resort can be made to instruments or principles of general international law to support an interpretation contra legem of Article $50 \mathrm{TEU}$. The procedure laid down in this provision constitutes lex specialis within a subsystem of international law, which in this case is EU law, as opposed to the lex generalis of the Vienna Convention on the Law of Treaties. Obviously, the latter can serve as a reference to fill possible gaps in Article 50 TEU.

Secondly, the (legal) interpretation of the provisions of Article $50 \mathrm{TEU}$, in cases of doubt or controversy, cannot be left exclusively to the negotiators. For example, if doubts arise about the

\footnotetext{
9 Another factor underlining how important it is that the general guidelines should clearly set out the terms on which negotiations are to be carried out in relation to Gibraltar is the possibility (which no one wishes to see materialise) that the final process of ratification might run into unexpected problems if the Gibraltar question is not properly addressed in the international agreement negotiated between the EU and the United Kingdom.
} 
revocability (or irrevocability) of the notification made under paragraph two of Article 50 TEU, it could not be decided that the British courts would be responsible for its implementation, as might be deduced, for example, from the ruling issued by the High Court of Justice of England and Wales on 3 November $2016^{10}$. Rather, this task would correspond to the CJEU, which according to Article I9.I TEU "shall ensure that in the interpretation and application of the Treaties the law is observed" (and not interpretation and application of the Treaties except for Article 50 TEU). Moreover, the above may be applicable, for example, to the possibility of bringing an action against the United Kingdom for failure to fulfil its obligations (i.e. for a breach of Union law) until such time as the withdrawal from the Union materialises; from that moment on, the situation would be determined in accordance with the provisions of the agreement reached between the Union and the United Kingdom ${ }^{\text {II }}$.

Thirdly, it is clear that the Union lacks the competence to negotiate with the United Kingdom regarding any aspect affecting the sovereignty of States, and this of course includes the question of Gibraltar. As established by the consolidated doctrine of the United Nations, Gibraltar is a nonautonomous territory pending decolonisation, a situation which violates the principle of the territorial integrity of Spain and to which the right to self-determination does not apply. The question of Gibraltar should be settled through negotiations between Spain and the United Kingdom, taking into account the interests of the population of the colony, and only the United Nations can decide when the process of the decolonisation of Gibraltar has been completed ${ }^{\text {r2 }}$. This, therefore, is the framework

Io Therefore, it does not seem readily defensible that the High Court of Justice of England and Wales, in its judgment of 3 November 2016 (Gina Miller and Tozetti Dos Santos v. The Secretary of State) addressed the question and considered that the notification was of an irrevocable nature; [2016] EWCH 2768 (Admin). A more likely outcome would be that, if the Court had any doubt in this respect, it would refer the question to the CJEU for a preliminary ruling, in the terms set out in Article 267 TFEU. A considerably more prudent outlook was shown by the Supreme Court of the United Kingdom in its judgment of 24 January 2017; [2017] UKSC 5 R v. Secretary of State for Exiting the European Union; on appeals from [2016] EWHC 2768 (Admin) and [2016] NIQB 85.About the controversy, see for example D. SARMIENTO, Miller, Brexit and the (maybe not so evil) Court of Justice; also P. CRAIG, 'Article 50 could be reversed, government may argue in Brexit case', The Guardian, I2 November 2016; HOUSE OF COMMONS: Brexit: Article 50 TEU and the EU Court, Briefing Paper No. 7763, London, 14 November 2016, pp. 9-II (with arguments for and against the revocability assertion).

II However, it should not be forgotten that some of the agreements concluded by the Union with third States provide for arbitration mechanisms to resolve disputes. Such, for example, is the case of the recent CETA Agreement with Canada (chapter 29, articles 29.I -29.19); COM (2016) final, 5 July 2016,

I2 The United Nations position on Gibraltar is clear and has remained unchanged for the last six decades. In 1946, the United Kingdom registered Gibraltar as a 'non-self-governing territory', pursuant to Chapter XI of the Charter of the United Nations. In 1963, Gibraltar was included in the list of territories subject to decolonisation. Accordingly, the United Nations Resolution on decolonisation (Resolution 1514 [XV] of 14 December 1960) is applicable, as it may readily be concluded that the colonial situation of Gibraltar destroys the national unity and territorial integrity of Spain ("Any attempt aimed at the partial or total disruption of the national unity and the territorial integrity of a country is incompatible with the purposes and principles of the Charter of the United Nations" - para. 6). In 1965, the UN General Assembly determined that the question of Gibraltar should be resolved through bilateral negotiations between Spain and the United Kingdom (Resolution 2070 [XX] of 16 December 1965). The General Assembly also considered that the 1967 referendum was contrary to the United Nations Resolutions applicable to Gibraltar (Resolution 2353 [XXII] of 19 December 1967). In 1968, the General Assembly expressly requested the United Kingdom, as the administering power, to put an end to the colonial situation of Gibraltar before I October 1969, declaring that maintaining this situation would be contrary to the purposes and principles of the Charter (Resolution 2429 [XXIII] of I8 December 1968). From then on, and after the issue was addressed by the 4th Committee, a consensus decision has been adopted every year, the core of which has remained unchanged (a call on the British and Spanish Governments to reach a definitive solution to the Gibraltar problem, one that is consistent with international law and with the relevant United Nations resolutions). Other aspects of these decisions have been modulated in accordance with the development of negotiations between the United Kingdom and Spain over the years. These comprise, basically, the Lisbon 
that the Union must necessarily respect in its negotiations with the United Kingdom.

Fourthly, EU law expressly recognises the bilateral nature of the dispute. Thus, the Act of Accession of Spain to the European Communities states that Spain's accession does not affect the respective positions of the two States with respect to Gibraltar and possible negotiating processes ${ }^{13}$. Indeed, CJEU case law is mindful of the international status of Gibraltar. For example, the Court has recognised that Gibraltar does not form part of the territory of the United Kingdom and is a colony ${ }^{14}$. Indeed, there is a CJEU ruling that acknowledges the existence of a dispute between Spain and the UK regarding the sovereignty of the isthmus ${ }^{15}$, as well as several other rulings condemning the United Kingdom for breach of Union law in this area ${ }^{16}$.

Fifthly, whatever general guidelines may be adopted by the European Council (general or concise, permanent or reviewable, etc.), it is clear that they require the support of the 27 Member States of the Union, including obviously that of Spain. This leaves an evident margin for action on issues that may affect the sovereignty of the State or its essential interests. Furthermore, this constitutes the most appropriate forum in which Spain may propose the insertion of an express reference, in the wording deemed fit, to the fact that the regime to be established for Gibraltar under the agreement negotiated by the Union and the United Kingdom must at least obtain the prior, explicit consent of Spain.

Sixthly, if opinions should be expressed contrary to the inclusion in the general guidelines of a reference such as that described in the previous paragraph, it should be recalled that, on various prior occasions, both the European Council and the European Parliament explicitly endorsed the negotiation process undertaken by Spain and the United Kingdom, in the past, to achieve a statute of cosovereignty ${ }^{17}$ and even invited the Commission to seek formulas to underpin "any agreement reached"

Declaration of Io April 1980, whereby the British and Spanish Governments undertook to resolve the Gibraltar problem in a spirit of friendship and in accordance with the relevant United Nations resolutions; the Brussels Declaration of 27 November 1984, in preparation for Spain's accession to the European Communities, which laid the foundations for a new negotiation process aimed at resolving all differences concerning the Rock, including those regarding sovereignty; the bilateral negotiations on sovereignty held in 200I-2002, in which an attempt was made to achieve a status of co-sovereignty; and the Tripartite Dialogue Forum, which also included Gibraltar and was inaugurated in 2004, and was intended to promote local and technical cooperation for the benefit of the population of the area.

Furthermore, the 'Committee of 24', holds a regional seminar on decolonisation each year, at which the United Nations position has invariably been confirmed. The last such seminar was held in Managua (Nicaragua) between 3I May and 2 June 2016; see $\mathrm{A} / 7 \mathrm{I} / 23$, especially pages $3 \mathrm{I}$ and 140 .

I3 See also the Exchange of Letters between Spain and the United Kingdom, done at Madrid on I3 June I985; BOE (Spanish Official Gazette) No. 291 of 5 December 1985.

${ }^{14}$ In its judgment of 23 September 2003, the CJEU acknowledged that "... the Treaty applies to Gibraltar as it is a Crown Colony for whose external relations the United Kingdom is responsible”; C-30/or, Commission v. United Kingdom, 47. See also the judgment of I2 September 2006, Case C-I45/04. Spain v. United Kingdom, I4 and I5; and the judgment of 2I July 2005, Case C-349/03 Commission v. United Kingdom, 4I.

is CJEU judgment of 29 June 1993, C-298/89, Government of Gibraltar v. Council, 22.

16 CJEU judgment of 20 October 2005, Case C-6/04 Commission v. United Kingdom, on the environment; judgment of $2 \mathrm{I}$ July 2005 in Case C-349/03 Commission v. United Kingdom, on mutual assistance between competent authorities of the Member States in the field of direct and indirect taxation. Several questions remain to be heard, in which British courts ask the CJEU whether relations between the United Kingdom and Gibraltar are purely internal situations (not subject to the freedoms of the internal market) or are intra-Community (and hence subject to the full force of these freedoms); see Gibraltar Betting o $\mathcal{F}$ Gaming (C-591/15) and Fisher (C-192/16) 22. In fact, there have been till now 28 cases regarding Gibraltar before the CJEU.

${ }_{17}$ See below, (C)(I). 
between the two States ${ }^{18}$. Therefore, it is all the more fitting to seek such an endorsement when one of the two States involved in the dispute is leaving the Union, as long as the dispute persists and clearly and directly affects the State which remains a member of the Union.

Seventh, and finally, it is quite apparent that when the United Kingdom withdraws from the Union, Gibraltar must also do so. When the UK ceases to be a Member State of the Union, Gibraltar's tie with Article 355.3 TFEU will disappear. The Member State in charge of Gibraltar's external relations will lose its membership and hence Union law will no longer be applied in the colony ${ }^{19}$. Certainly, creative solutions to this situation might be floated, but, as we show below, any such solution must, in the end, be compatible both with the framework of international law established by the United Nations and with the framework of Union law established by Article $50 \mathrm{TEU}^{20}$.

Accordingly, worn-out phrases such as 'Brexit means Brexit' or 'hard Brexit versus soft Brexit' do not contribute anything from the legal perspective and yet, from the political standpoint, they muddy the waters of negotiations. It would therefore be useful to consider the following specific proposal put forward by Spain as a possible satisfactory solution to the dispute on Gibraltar.

(C) THE PROPOSAL FOR SHARED SOVEREIGNTY: A POSSIBLE SATISFACTORY SOLUTION TO RESOLVE THE DISPUTE OVER GIBRALTAR

\section{(I) The revival of an old proposal in a favourable context: the right time for its implementation in accordance with international and $\mathrm{EU}$ law}

\section{(a) The (unsuccessful) precedent of 200I-2002}

Since the second half of the twentieth century, Spain has made several proposals for a negotiated solution with the United Kingdom to recover the sovereignty ceded by Spain under the 1713 Treaty of Utrecht $^{21}$. For this reason, the current proposal is not really new, and it has at least two direct

I8 In particular, the European Council welcomed "the decision of the United Kingdom and Spain to relaunch the Brussels Process on Gibraltar, established in November 1984" and stressed its "support for both Governments' commitment to overcoming their differences over Gibraltar, and to conclude a comprehensive agreement before the summer [of 2002]; and invites the Commission to explore possible ways in which the EU could underpin any agreement reached" (Conclusions of the European Council, Barcelona, I5-16 March, para. 56). The European Parliament, for its part, welcomed "the relaunch of the 1984 Brussels process on Gibraltar" and stated that it "supports the UK and Spanish governments' attempts to conclude an agreement before summer 2002 and invites the Commission to explore possible ways in which the EU could underpin any agreement reached" (European Parliament Resolution of 20 March 2002, para. 39).

19 This is even recognized by the House of Lords. See HOUSE OF LORDS: Brexit and Gibraltar, loc. cit. (Note 4).

20 See below (D).

${ }^{21}$ It should not be forgotten that the title of sovereignty of the United Kingdom derives exclusively from Article $\mathrm{X}$ of the Treaty of Utrecht of 1713 , which ceded the city and the castle of Gibraltar, together with its port, and the fortifications and forts that belong to it. Spain at no time ceded the isthmus, territorial waters or the airspace above the territory, and therefore Spain does not recognise as belonging to the United Kingdom any spaces other than those expressly included in Article X of the Treaty of Utrecht. Accordingly, the only waters it recognises are the internal waters of the port, and precisely for this reason, the appropriate declarations were made when Spain signed and ratified the United Nations Convention on the Law of the Sea of 1982. Finally, the cession made was without any communication by land with the rest of Spain. This means that, in Spain's view, both the occupation of the isthmus by the United Kingdom during the nineteenth century and the construction of the airport on the isthmus are illegal and contrary to international law. In addition, Spain has a preferential right to recover the territory if the British Crown decides to grant, sell or alienate it. See in extenso Ministry of Foreign 
precedents $^{22}$. The first dates back to 1998, when Abel Matutes was Spanish Foreign Minister. The second, which was much more detailed, took place during intense negotiations during $200 \mathrm{I}$ and 2002 between the Ministers Josep Piqué and Jack Straw, who apparently came very close to reaching a final agreement. From the public statements made by some of the leading participants in these negotiations, it seems that the main hurdles remaining to a final agreement were whether the agreement should have a lasting character (Spain's position) or be definitive (the UK standpoint), whether a referendum should be held in Gibraltar and, of course, the Naval Base. In any case, according to those best acquainted with these negotiations, it seems that a final agreement was almost within arm's reach.

Before the final phase, a number of working meetings were held, ranging from contacts at the highest level (heads of government) to technical preparation meetings, together with the impetus provided at ministerial level (Piqué-Straw) in a large number of meetings held between November $200 \mathrm{I}$ and May $2002^{23}$. Be that as it may, the negotiations ultimately broke down and all that remains is for historians to study how near or far we were from real agreement. It was, in any case, an experience of considerable interest, which we can now learn from, to identify what went right and exactly where mistakes were made.

\section{(b) The (favourable) context today}

However, the current context of Brexit is a golden opportunity to resume these negotiations and to seek a definitive resolution to a colonial dispute that has gone on for far too long. We fully agree with Alejandro del Valle Gálvez in that "Brexit has created a new legal playing field, in Europe and beyond, with new rules. But it also offers a historic moment for Spain to redefine its relationship with Gibraltar, providing opportunities for new formulas to be considered, seeking new ways forward and a solution to this age-old dispute" ${ }^{24}$. We also agree with this author that "this moment in time may even be propitious for new, creative formulas to be advanced"25. In our view, there are solid reasons for arguing, in the first place, that the question of sovereignty over Gibraltar should be excluded from the negotiations on Brexit and, therefore, that it should be agreed bilaterally between the United Kingdom and Spain. Within the framework of Union law, at least four different arguments could be advanced to support this view.

Firstly, the Union lacks competence in matters of sovereignty. Hence, it seems logical to hold that questions directly affecting this issue cannot be addressed in the Brexit negotiations, into which the

\footnotetext{
Affairs and Cooperation, The question of Gibraltar, Madrid, 2008.

22 It does not seem necessary, in this respect, to refer to the earlier precedents of Fernando María Castiella (Negociaciones sobre Gibraltar presentado a las Cortes Generales por el Ministro de Asuntos Exteriores, Madrid, I966, usually known as the Red Book) and Fernando Morán, as their context and content differ considerably from those of the current proposal.

${ }_{23}$ Some details of this negotiating process can be found in the interesting memoirs of Peter Hain, 'Outside in', Bitteback Publishing, London, 2012, especially pp. 274-284. Nevertheless, it is important to bear in mind, in assessing some of the statements made in this book, that Hain did not participate directly in the meetings with Minister Piqué, a role that was played by Straw, although several meetings were also held between Hain and the then Spanish Secretary of State for the European Union, Ramón de Miguel. Minister Straw's appearance before the British Parliament on the summer of 2002 is also an invaluable source for properly assessing the scope and seriousness of the negotiations that took place.

24 “Gibraltar, 'año cero': Brexit, cosoberanía y nuevas oportunidades de España”, [Gibraltar, 'year zero: Brexit, cosovereignty and new opportunities for Spain] Real Instituto Elcano, ARI 75/2016, 20 October 2016, p. I.

${ }_{25} \quad$ Ibid., p. I6.
} 
Union will enter under the terms laid down in Article 50 TEU. Secondly, the Union has a duty to uphold respect for the constitutional identity of its Member States and for the essential functions of each State, especially those aimed at preserving its territorial integrity (Article 4.2 TEU). Since sovereignty is the basic principle on which constitutional identity and essential functions rest, this too warrants being safeguarded by the Union. Thirdly, since the dispute over Gibraltar must be resolved bilaterally between the United Kingdom and Spain, in accordance with international law and longestablished United Nations doctrine on decolonisation, the Union has a well-grounded basis on which to maintain the position we defend. There are, indeed, very significant precedents in secondary EU legislation, whereby the inclusion of references in EU decisions that might be controversial in relation to Gibraltar have been made subject to the outcome of bilateral negotiations ${ }^{26}$. Fourthly, the CJEU's own jurisprudence provides support for this interpretation. The highest judicial instance of the Union has expressly recognised the colonial nature of Gibraltar, the non-inclusion of Gibraltar in the territory of the United Kingdom and the existence of a dispute between Spain and the United Kingdom with respect to the sovereignty of the isthmus ${ }^{27}$. That aside, on various occasions the Court has also found the United Kingdom (via Gibraltar) in breach of Union law.

That being said, let us now detail the scope of the Spanish proposal.

\title{
(2) Scope of the Spanish proposal for shared sovereignty: an offer with advantages for all (but probably also involving some sacrifices for all)
}

An appropriate legal approach to the Spanish proposal on shared sovereignty requires, in our opinion, that two considerations be made: the first is a material one, to specify its content, and the second is procedural, to specify how the proposal in question could be articulated in practice.

\section{(a) Material aspects}

Starting with material aspects, the speech by Spain's Permanent Representative to the United Nations, on 4 October $2016^{28}$, contains the essential elements of the Spanish proposal for co-sovereignty:

\begin{abstract}
"Faced with this situation [Brexit], we would like to propose a solution. I would like to announce today, before this Commission, that Spain has formally invited the United Kingdom to open negotiations enabling us to reach an agreement so that the provisions of the EU treaties may continue to apply to Gibraltar. With EU law as it stands, the only possibility for this to be the case once the United Kingdom has left the EU is for there to be a political tie between Gibraltar and Spain - which will continue to be an EU member. We would like to reach an agreement with United Kingdom on a joint sovereignty system which would enable Gibraltar to stay in the EU, and based on the recognition of as broad a self-government as possible - which is compatible with Spain's constitutional system - and on an advantageous personal status for Gibraltarians, which could include dual nationality"29.
\end{abstract}

Subsequently, and having clarified that "Spain will never relinquish its just claim and its aspiration of

${ }_{26}$ This is the case, for example, of European legislation on air traffic and airports.

27 See above, notes 15 -17.

28 Speech by the Permanent Representative of Spain to the United Nations on 4 October 20r6. A summary of this is published, as indicated above, in A/C.4/7I/SR.3, pp. 3-4. The full version of the speech to the IV Committee of the United Nations was distributed during the meeting.

29 Ibid 
reaching a definitive settlement to the question of Gibraltar in line with the relevant resolutions of the General Assembly and the applicable principles under the Charter Of the United Nations", the Permanent Representative of Spain specified the material scope of the proposal, detailing four fundamental elements, which constitute the nucleus of the Spanish offer:

"The proposal that Spain is making to the United Kingdom revolves around four major issues:

I. A personal status for the inhabitants of the Rock that will enable them to retain British nationality, opening the possibility of also attaining Spanish nationality without having to renounce the former.

2. Maintenance of Gibraltar's self-governing institutions within the framework of a wide-ranging system of autonomy, which would very easily fit in with Spain's constitutional system.

3. Maintenance of Gibraltar's special tax regime, insofar as it is compatible with EU law.

4. Dismantling the fence separating Gibraltar from the rest of the Iberian Peninsula, which the United Kingdom erected in 1909 .

$S$ pain and the United Kingdom would jointly exercise authority over matters of defence, foreign relations, control of external borders, immigration and asylum"30.

In line with this new scenario, the 2016 Decision of the General Assembly on the question of Gibraltar, agreed between Spain and the United Kingdom, represents a significant development over previous years. In addition to the traditional paragraph in which the General Assembly urges the Governments of Spain and the United Kingdom to reach a definitive solution to the question of Gibraltar ${ }^{31}$, two new paragraphs have been inserted, making reference to the new situation. On the one hand, Spain achieved the inclusion of an express reference to its new proposal for shared sovereignty, as follows:

"[The General Assembly] Takes note of the position of Spain on this issue, including its proposal to start new discussions on the basis of the Brussels Declaration, and also takes note of Spain's presentation of a co-sovereignty offer before the Special Political and Decolonization Committee"s2.

In exchange for achieving the inclusion of this text, Spain accepted a new paragraph in which the United Kingdom also alluded to its well-known position that any agreement adopted should take into account the wishes of the people of Gibraltar:

"[The General Assembly] Takes note of the position of the United Kingdom on this issue, that is, the commitment never to enter into arrangements under which the people of Gibraltar would pass under the sovereignty of another State against their freely and democratically expressed wishes, nor enter into a process of sovereignty negotiations with which Gibraltar is not content" ${ }^{\prime 3}$.

It should be pointed out that in legal terms there is a considerable difference between the first paragraph, in which the Governments of the two States are "urged" to reach a final negotiated solution, and paragraphs two and three, in which the General Assembly merely "takes note" of the respective positions on shared sovereignty (Spain) and on taking into account the wishes of the people of Gibraltar (United Kingdom). In other words, the United Nations mandate remains limited to the

30 Ibid.

${ }^{3}$ In particular, the General Assembly "Urges the Governments of Spain and the United Kingdom of Great Britain and Northern Ireland, while listening to the interests and aspirations of Gibraltar that are legitimate under international law, to reach, in the spirit of the Brussels Declaration of 27 November 1984, a definitive solution to the question of Gibraltar, in the light of the relevant resolutions of the General Assembly and applicable principles, and in the spirit of the Charter of the United Nations".

32 UN Doc. A/C.4/71/L.I7.

33 Ibid. 
requirement that Spain and the United Kingdom reach "a final settlement of the question of Gibraltar in the light of the relevant General Assembly resolutions and applicable principles, and in accordance with the spirit of the Charter of the United Nations". And to (re)commence these negotiations, Spain has in good faith put forward a concrete proposal on which to negotiate ${ }^{34}$.

\section{(b) Procedural aspects}

As regards procedural aspects, the legal mechanism for addressing the proposal would depend to a large extent on the content of the material agreement in question and on the willingness of the parties (United Kingdom and Spain) in this regard. However, in view of the issues to be taken into consideration and the direct consequences thereof in areas which obviously correspond to the circumstances provided for in Articles 93 and 94.I of the Spanish Constitution, it seems clear that, in any event, an international treaty would be called for and that such a treaty would require the prior authorisation of the Spanish parliament. However, from an operational standpoint, the legal implementation of the process could be performed in two stages. Once the negotiation was concluded, a (political) declaration by the Spanish and British governments could be adopted, concisely presenting the general terms of the agreement reached. Subsequently, in a second stage, the terms of the agreement could be drawn up (legally) through the conclusion of an international treaty that would be subject to the corresponding domestic parliamentary procedures prior to the provision of consent by both States. Logically, from a political perspective, the stumbling block that must be addressed is that of the role to be played by the inhabitants of the colony. In strictly legal terms, United Nations doctrine requires that the settlement negotiated by the United Kingdom and Spain should "take into account the interests of the population of the colony", which in no way can be equated directly with holding a referendum on the question. Now is not the time to dwell on this issue, although various political and legal solutions to this question may be considered. For example, and as the Permanent Representative of Spain also proposed in his speech of 4 October 2016 to the 4 th UN Committee, a representative from Gibraltar could form part of the British delegation and thus be present and informed throughout the bilateral process of negotiations ${ }^{35}$.

Finally, as concerns Spain specifically, it would be useful to consider the impact of the provisions of Article 144 of the Spanish Constitution, which was drafted in 1978 with Gibraltar in mind, as well as those contained in the Statute of Autonomy of Andalusia. But in any case, the proposal for shared sovereignty does not necessarily require territorial integration in Spain. Various possibilities may arise for achieving a (lasting) solution to the dispute.

34 As mentioned above, we fully agree with Alejandro del Valle with respect to proposing creative solutions (see above, Notes 24 and 25). However, we do not fully grasp what this author is referring to when he states that "the proposal for sovereignty announced by the acting Spanish Government has the format and contents of others that have been presented or negotiated previously" (page 16) and speaks of "proposing reasonable and pragmatic means of resolving the historical dispute" (page 17). At heart, the reference to a "sovereignty in common by means of the formula of the City under the British and Spanish Crowns", as posited by Alejandro del Valle, is not so very far from the proposal made by Spain. And obviously it can be subject to negotiation. As regards this author's earlier position on Gibraltar, see among other works "España y la cuestión de Gibraltar a los 300 años del Tratado de Utrecht" [Spain and the question of Gibraltar, 300 years after the Treaty of Utrecht], Royal Institute Elcano ARI 23/2013, dated 20 June 2013.

35 In loc. cit. (Note 28 ). 
(D) THE CHIMERA OF 'CREATIVE SOLUTIONS': GIBRALTAR IS NOT A STATE AND GREENLAND IS NOT A COLONY

\section{(I) The non-applicability of the alleged parallels with Greenland or with micro-States: Gibraltar is (simply) a colony}

At this point, let us provide a legal answer to some of the 'creative solutions' which, in Gibraltar's view, could allow this colony to maintain unchanged its connection with the EU despite the fact of withdrawal by the United Kingdom. Indeed, with the aim of achieving "the best of both worlds" ${ }^{36}$, one of Gibraltar's representatives has seriously advanced the possibility of exploring a joint approach with Scotland, to study the possible precedent of Greenland or of the micro-States ${ }^{37}$. However, in our view, the references to other circumstances have little (or nothing) to do with Gibraltar's legal status. Let us summarise the different possibilities suggested.

One approach that has been suggested in order to elude the consequences of Brexit is to try to establish a point of comparison between Gibraltar and what has been termed, with considerable ingenuity, 'reverse Greenland'. However, there is little scope for comparison between a colony and the territory of a Member State with a special regime (in this case, 'overseas territory'); one, moreover, that has been recognised by a Protocol approved by all the Member States ${ }^{3}$. Greenland is not a colony, Gibraltar is; and Denmark remains a Member State of the Union, while the United Kingdom after Brexit would not. Scant parallelism, thus, can be discerned.

Equally inappropriate, in our view, is the proposal by the Chief Minister of Gibraltar to seek a possible special regime for the application of EU law to Gibraltar, following Brexit, in line with that granted to the so-called micro-States (Andorra, San Marino and Monaco) ${ }^{39}$. Certainly, both types of territory share common elements (such as having a very restricted land surface area and a small population), but they are also differentiated by an insurmountable difference. While the three territories mentioned above are subjects of international law and possess statehood, Gibraltar is a nonautonomous territory pending decolonisation ${ }^{40}$. It is therefore hard to conceive of any kind of international treaty being concluded between the EU and Gibraltar. Not to mention the requirement that any agreement with/on Gibraltar must obtain prior support from Spain.

36 This was the title, for example, of the document which the British Government presented to Parliament in February 2016 to defend the decision adopted by the Heads of State and Government seeking to maintain the United Kingdom's presence within the EU; HM GOVERNMENT: The best of both worlds: the United Kingdom's special status in a reformed European Union, London, 2016. Of greater current value is the White Paper presented in February 2017 by Prime Minister Theresa May; HM GOVERNMENT: The United Kingdom's exit from and the new partnership with the European Union, London, 2017.

37 See Paz Andrés Sáenz de Santa María, "La nueva propuesta española de soberanía conjunta: Gibraltar en la encrucijada postBrexit" [The new Spanish proposal for co-sovereignty: Gibraltar at the post-Brexit crossroads], 4I Revista General de Derecho Europeo (2017) I-I4.

38 See Article 204 and Annex II TFEU and Protocol 34.

39 See, for example, his appearance on I3 December 2016 before the Lords Select Committee on the European Union, where he explicitly considers that "we may seek that the United Kingdom's negotiation includes a facet that allows Gibraltar to have a microstate-style relationship with the EU”. Available at the website of the British Parliament at http://www.parliament.uk.

40 See Julianne Kokott, "Micro-States", in Rudolf Bernhard (ed.), Encyclopedia of Public International Law, III, (I997), p. 362. 
Still less appropriate is it to cite so-called precedents such as Algeria or German reunification. The first is an obvious case of decolonisation, which until the Maastricht Treaty did not even entail a legal change in the initial reference made in the founding treaties (former Article 227.2 TEEC). And the second is simply a case of absorption of a third State by an EU Member State, which took place after the dissolution of the German Democratic Republic and the incorporation of its territory and population into the Federal Republic of Germany (the Two plus Four Moscow Treaty and the Reunification Treaty), and had an express provision in the Fundamental Law of Bonn (former Article 23); there were even indirect references in the founding treaties to the 'division of Germany' as regards public aid (former Article 87.2 c TEEC) and transport (former Article 78 TEEC).

Finally, some opinions have been voiced regarding the possible regulation of a special regime for Gibraltar, following Brexit, on the basis of the Union's alleged flexibility, as well as the specificities presented by the Union in terms of the territorial modulation of international agreements into which it has entered, by means of special clauses. Nevertheless, this argument has no basis in fact, either. The EU may indeed be flexible. But there is no basis whatsoever for arguing the existence of recent international agreements with such clauses. Thus, examination of the 53 agreements concluded by the Union since 2010 with non-member States shows that only four include some kind of clause modulating their territorial application; and none of them establishes a special regime. On the contrary, they confine themselves to recognising the objective fact that the State with which the agreement is concluded does not control part of its territory ${ }^{41}$.

\section{(2) Not everything can be shoehorned into negotiations on the future of Gibraltar in the context of Brexit: the founding treaties present absolute limits to the imagination}

In short, from the points made above, it is plain that not everything can be fitted into the negotiation on the future of Gibraltar within the framework of Brexit. Certainly, a flexible approach to the issue may be considered. But neither the Union nor Spain can accept any type of proposal that is not compatible with the founding treaties and with international law. The Gibraltarian authorities may express all the imagination they see fit and can legitimately hope that the United Kingdom will reach an agreement that is as favourable as possible to the interests of the Member State leaving the Union and, hence, to those of the territories for whose external relations it is responsible. But in no way can they aspire to a regime that is contrary to the founding treaties (without the legal bond of Article $355 \cdot 3$

${ }_{4 \mathrm{r}}$ This is the case of the agreements concluded with the Republic of Korea (OJEU L I27 of I4 May 2011, Article 15.15), with Central America (OJUE L 346 of 15 December 2012, Article 360), with the Republic of Moldova (OJEU L 260 of 30 August 20I4) and Georgia (OJEU L 26I of 30 August 20I4). To be precise, in the case of the free-trade agreement with the Republic of Korea, the 'territorial application' clause merely states that "References to 'territory' in this Agreement shall be understood in this sense, unless explicitly stated otherwise" (Article 15.15). In the case of the Agreement with Central America, the territorial reference merely indicates that the application of the Agreement shall be "in accordance with their respective domestic legislation and international law" (Article 306). In the case of Moldova, the territorial application clause clearly refers to areas "over which the Government of Moldova does not exercise effective control" (Article 462.2). And in the case of Georgia, a similar situation arises, and the text states "Georgia's regions of Abkhazia and Tskhinvali region/South Ossetia over which the Government of Georgia does not exercise effective control” (Article 429.2). These are all cases that have nothing whatsoever to do with Gibraltar. 
there is no possible applicability of EU law to Gibraltar) or to United Nations doctrine in this respect (i.e., that Gibraltar is a colony pending decolonisation, the dispute regarding which must be settled through negotiations between Spain and the United Kingdom).

Furthermore, of course, the above-cited agreement between the Union and the United Kingdom must also be endorsed by Spain, both as concerns determining (by consensus) the general guidelines to be adopted at the European Council and, probably, also as concerns eventual ratification of the agreement establishing future relations between the Union and the United Kingdom, via the corresponding authorisation for ratification by the Spanish Parliament. Imagination, therefore, can be given free rein, but always in the understanding that Article 50 TEU, the doctrine of the United Nations and the role of the 27 Member States in the negotiation process set very clear boundaries to the process.

(E) FINAL CONSIDERATIONS: A REASONABLE PROPOSAL WITH ADVANTAGES FOR ALL

At this point, then, some preliminary conclusions can be drawn regarding the question of Gibraltar in the context of Brexit. The unavoidable starting point is that the withdrawal of the United Kingdom from the Union will inevitably produce the withdrawal, too, of Gibraltar, since the legal tie established by Article 355.3 TEU will disappear.

Secondly, there is no legally acceptable justification for seeking 'precedents' by reference to microStates or to the notion of 'reverse Greenland' to bring about the chimera that Gibraltar could remain within the Union even if the United Kingdom were no longer a Member State. Gibraltar does not possess statehood, and therefore cannot be considered a micro-State. And the status of Greenland has nothing to do with that of Gibraltar, since Denmark continues to be a Member State of the Union. In fact, the status of Greenland has nothing in common with that of a colony in the sense determined by the United Nations; moreover, its regulation was established under an agreement accepted by all the Member States of the Union, and stipulated thus in an ad boc protocol.

Thirdly, the loss of the connection between Gibraltar and the EU, with the non-applicability of Article 355.3 TEU, would have very negative consequences, both for Gibraltar and for the Spanish population of Campo de Gibraltar, since EU law would no longer be applicable in the territory. In such a case, relations between Gibraltar and the Union would be governed by the conditions laid down in the agreement between the Union and the United Kingdom, which would have to be reached by means of the procedure set out in Article 50 TEU. Logically, this could not be done without the support of Spain (and of the other 26 Member States).

Fourthly, the agreement governing relations between the United Kingdom and the EU should not include the 'question of Gibraltar'. As Gibraltar is the object of a dispute over sovereignty, over which the Union has no jurisdiction, the bilateral Spanish-British approach should be scrupulously respected in the negotiations held between the EU and the United Kingdom. Therefore, the question of sovereignty over this territory should be excluded from the latter negotiations and be addressed exclusively in a bilateral negotiation between Spain and the United Kingdom. This reasoning is in full accordance with United Nations doctrine and also with EU law (the Act of Accession of Spain to the 
European Communities).

Fifth, and most important of all, failure to seize the window of opportunity offered by the Brexit context regarding the Gibraltar question would squander a golden opportunity to finally achieve a negotiated solution between the United Kingdom and Spain, one taking into account the legal framework established by international law (and especially the doctrine of the United Nations) and the interests of all inhabitants of the area. The present context is favourable for such a solution; it has not occurred in the past and is unlikely to reappear soon.

We believe, therefore, that Spain's proposal for shared sovereignty is beneficial to all: for the United Kingdom and Spain, first of all, but also for the people of Gibraltar and for the inhabitants of Campo de Gibraltar, and even for the EU. It is good for the UK and for Spain, because it would put an end to a colonial situation that has lasted for over 300 years and which is difficult to justify in the current international context, and because it would further enhance the friendly relations enjoyed between the two States. It is good for Gibraltar, because it would maintain the wished-for application of EU law, by making Spain (jointly with the UK) responsible for external relations, and thus maintaining the link with the EU through Article 355.3 TEU; moreover, if the case arose, the population of Gibraltar would enjoy a wide margin of political autonomy under Article I44.b of the Spanish Constitution and could acquire, if they wished, Spanish nationality, without renouncing their British nationality. The proposal is also good for the local (Spanish) inhabitants, by bringing about the disappearance of the Fence and by notably strengthening mutual economic relations, thus boosting development and well-being throughout the area. And it is also good for the EU itself, because it would remove an uncomfortable obstacle which could hinder negotiations between the United Kingdom and the Union to regulate the former's withdrawal and the establishment of future relations with the EU.

Summing up, the present moment is a delicate one that we should make the most of. All those involved should act with the clear thinking and far sightedness called for by the historic responsibility of this moment. As has been observed by an unimpeachable source, this may be an opportune occasion for addressing a solution to the Gibraltar question, one in which "Facing outwards, now is the time for diplomacy, but facing inwards, there must be dialogue with all the political parties and public administrations concerned, in order, once and for all, to make Gibraltar a shared question of State" ${ }^{42}$ The offer made by Spain to negotiate a statute of shared sovereignty is, in our opinion, an interesting proposal that merits consideration. As the Permanent Representative of Spain to the United Nations said in his address to the Fourth Committee, "We believe, in sum, that this proposal is a good deal for all of us: for Spain, for the United Kingdom, for Gibraltar and for Campo de Gibraltar. So why not sit down and talk?" 43

42 Paz Andrés Sáenz de Santa María, loc. cit. (Note 37), p. I4 in fine.

43 Loc. cit. (Note 28). 